Section Editor

John J. Millichap, MD
Pierre Bailly, MD

Jean-Baptiste Noury

Serge Timsit, MD, PhD

Douraied Ben Salem,

$\mathrm{MD}, \mathrm{PhD}$

Correspondence to

Dr. Bailly:

pierre.bailly@chu-brest.fr
Teaching NeuroImages:

\section{Ornithine transcarbamylase deficiency revealed by a coma in a pregnant woman}

Figure 1 T2 fluid-attenuated inversion recovery axial MRI

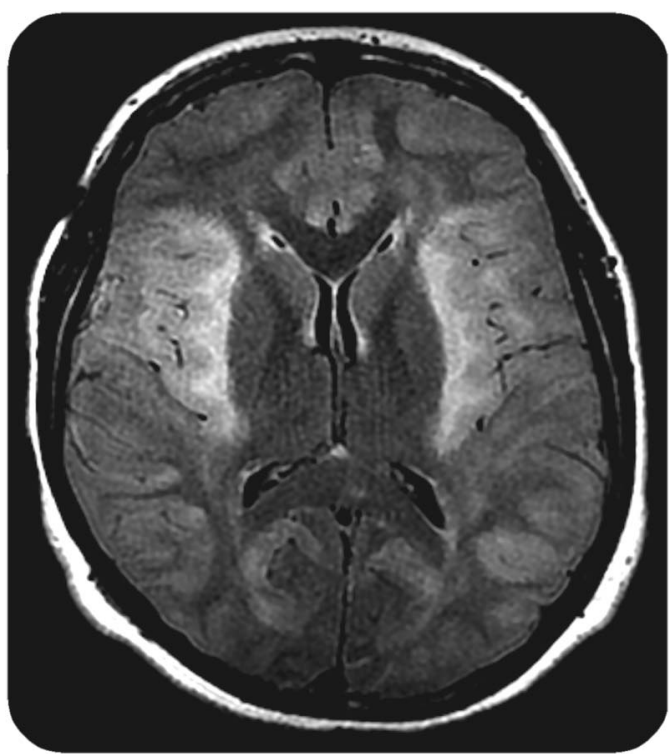

Bilateral temporal, peri-insular, and frontal cortex hypersignal and thickening, with thalami sparing. Subcortical $U$ fibers were affected.

A 32-year-old pregnant (20 weeks of amenorrhea) woman, after change in dietary intake (due to a trip to Korea), developed over 3 weeks progressive neuropsychological disorders associated with behavior disorders. The patient rapidly worsened, and had impaired consciousness and a coma. Biological tests showed hyperammonemia $(173 \mu \mathrm{mol} / \mathrm{L})$, glutamine chromatographic peak, and increased urinary orotic acid concentration. Brain MRI (figure 1) and spectroscopy (figure 2) findings were consistent with urea cycle disorders. ${ }^{1,2} \mathrm{~A}$ novel heterozygous mutation p.Ala209Glu (c.626C >A) in OTC gene was identified. She was treated with sodium benzoate, sodium phenylacetate, citrulline, hemofiltration, and reduced protein intake. Consciousness improved, and pregnancy was carried to completion, but mild cognitive impairment persisted 3 months later. The baby girl also carried the mutation but had no sequelae at 11 months.

\section{AUTHOR CONTRIBUTIONS}

Pierre Bailly and Jean-Baptiste Noury took care of the patient in the ICU and wrote the article. Serge Timsit's opinion was requested to confirm diagnosis. He read and corrected the article. Douraied Ben Salem performed the MRI. He read and corrected the article.

\section{STUDY FUNDING}

No targeted funding reported.

\section{DISCLOSURE}

The authors report no disclosures relevant to the manuscript. Go to Neurology.org for full disclosures.

\section{REFERENCES}

1. Bireley WR, Van Hove JL, Gallagher RC, Fenton LZ. Urea cycle disorders: brain MRI and neurological outcome. Pediatr Radiol 2012;42:455-462.

2. Gropman A. Brain imaging in urea cycle disorders. Mol Genet Metab 2010;100(suppl 1):S20-S30.
Download teaching slides: Neurology.org 


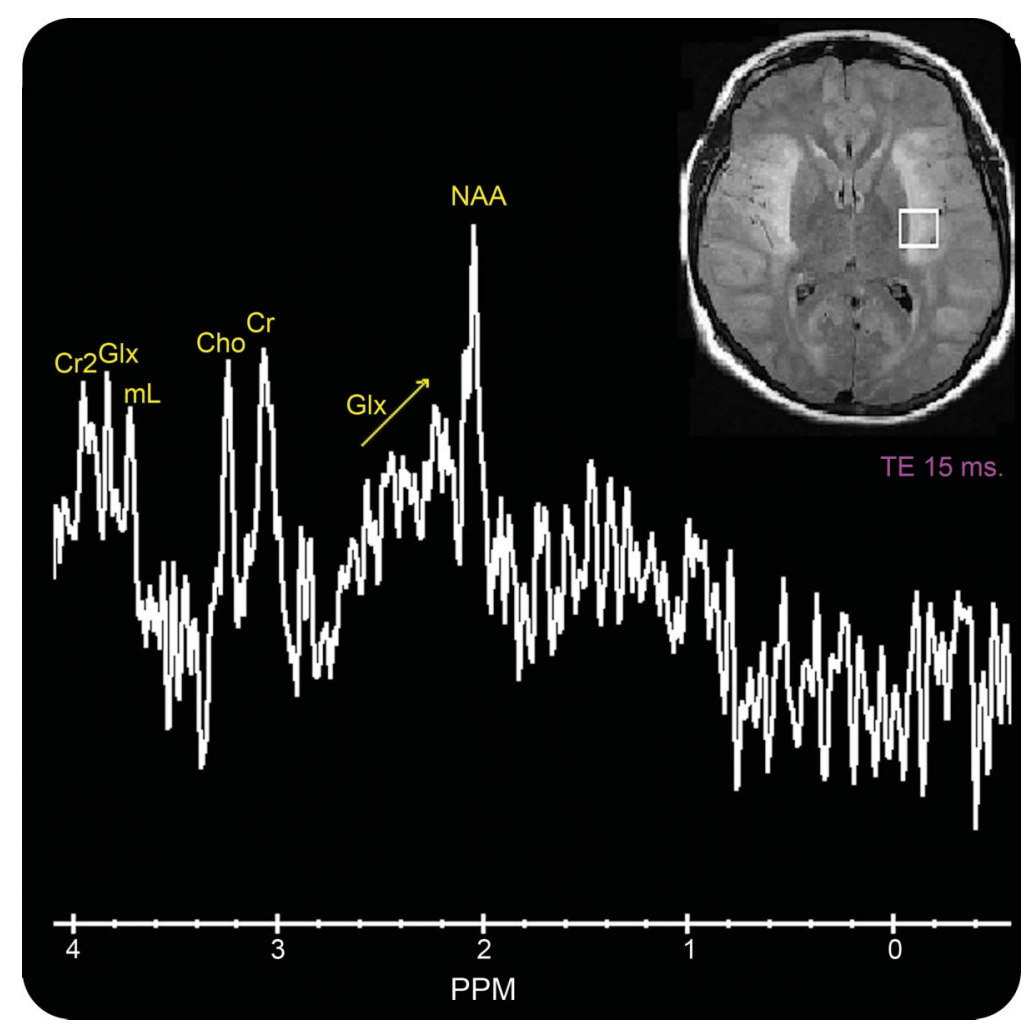

Increased levels of glutamine-glutamate (GIx) and slight decrease in levels of myo-inositol (ml). The arrow indicates Glx peaks. Typical MRI and MRS findings in ornithine transcarbamylase deficiency are T1 and T2 hypersignals, located in the cerebral cortex, preferentially in peri-insular regions and the basal ganglia and an increase in Glx. This is due to the excess of ammonia and is not pathognomonic of urea cycle disorders. $\mathrm{Cr}=$ creatine; Cho $=$ choline; $\mathrm{NAA}=\mathrm{N}$-acetylaspartate; $\mathrm{TE}=$ echo time. 


\section{Neurology}

\section{Teaching NeuroImages: Ornithine transcarbamylase deficiency revealed by a coma in a pregnant woman}

Pierre Bailly, Jean-Baptiste Noury, Serge Timsit, et al. Neurology 2015;85; e146-e147

DOI 10.1212/WNL.0000000000002131

\section{This information is current as of November 16, 2015}

\section{Updated Information \&} Services

Supplementary Material

\section{References}

Subspecialty Collections

Permissions \& Licensing

Reprints including high resolution figures, can be found at: http://n.neurology.org/content/85/20/e146.full

Supplementary material can be found at: http://n.neurology.org/content/suppl/2015/11/14/WNL.0000000000002 131.DC1

This article cites 2 articles, 0 of which you can access for free at: http://n.neurology.org/content/85/20/e146.full\#ref-list-1

This article, along with others on similar topics, appears in the following collection(s):

All Genetics

http://n.neurology.org/cgi/collection/all_genetics

Coma

http://n.neurology.org/cgi/collection/coma

Critical care

http://n.neurology.org/cgi/collection/critical_care

Metabolic disease (inherited)

http://n.neurology.org/cgi/collection/metabolic_disease_inherited MRI

http://n.neurology.org/cgi/collection/mri

Information about reproducing this article in parts (figures,tables) or in its entirety can be found online at:

http://www.neurology.org/about/about_the_journal\#permissions

Information about ordering reprints can be found online:

http://n.neurology.org/subscribers/advertise

Neurology ${ }^{\circledR}$ is the official journal of the American Academy of Neurology. Published continuously since 1951, it is now a weekly with 48 issues per year. Copyright @ 2015 American Academy of Neurology. All rights reserved. Print ISSN: 0028-3878. Online ISSN: 1526-632X.

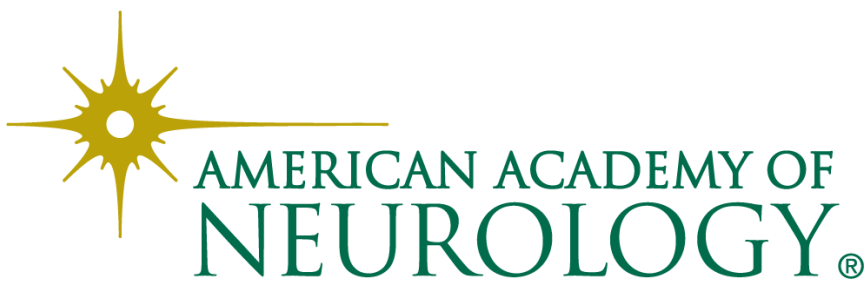

